\title{
Ethnoarchaeological Study of Pottery Tradition in Usambe, Ikyurav-Ya, Southeastern Tiv Land, Benue State, Nigeria
}

\author{
Terngu S. N omishan \\ Department of Archaeology \\ A hmadu Bello University, Zaria-Nigeria \\ DOI: https:/ / doi.org/ 10.33281/ JTHS20129.2017.2.4
}

\begin{abstract}
Pottery production has been recognized as one of the ancient Tiv practices that have survived to this day. Therefore, whenever remains of pottery objects are identified at an archaeological site within the Tivland, they usually contain tangible information regarding the group that made and used them. This research is an ethnoarchaeological investigation of pottery tradition in U sambe community. The researcher uses ethnographic information on pottery production and usage in the area to infer about the cultural formation process, growth and advancement of the Tiv people that made and used clay wares found in fragments on the hills of $U$ sambe. The results, however, align with the position of various scholars of Tiv tradition that the hills located in the present $U$ sambe community are among the hills inhabited by the Tiv people during their exodus into the Benue Valley of Nigeria.
\end{abstract}

Keywords: Ethnoarchaeology, Pottery making, Tivland, Usambe community.

\section{Introduction}

The main objective of archaeology is to reconstruct the lifeways of the people responsible for the archaeological remains (Renfrew and Bahn 1991), and to synthesize the knowledge of human material remains from the past in the context of time and space, in order to recreate the history of man in its true cultural and physical environment (Krishna, et al' 1967).

To reconstruct the past, archaeologists deal with various data, among which are finds like pottery remains. Pottery remains are the products of clay pots, which are first shaped, sun- dried and fired so as to make the original substance lose its physical and chemical properties and change into a hardened form (Billington, 1962). Pottery is, therefore, a product of people's technological advancement born out of the desire for their material needs (A remu, 2004).

According to Bakinde (2004), once the clay is fired, it becomes highly resistant to decay and almost indestructible, and cannot under any given condition be reverted to its former state. Therefore, once pottery is discovered in an archaeological site, it helps in reconstructing the cultural past of the society under study. It also helps the archaeologists to infer the trade pattern among various societies, as well as to establish dates on sites 
through radiocarbon dating (C-14) method and also serve as evidence of cultural contact between various groups.

To reconstruct the past pottery behaviour of a people, archaeologists make use of ethnological apparatus among other approaches. The recognition of the need to use ethnographic material to consolidate archaeological data gave rise to a new sub-discipline called 'Ethnoarchaeology', an approach, derived from the need by archaeologists to look at surviving societies from the point of view of archaeology. "The subdiscipline is neither a theory nor a method, but a research strategy. It embodies a range of approaches both in the living context and to understand archaeological records in order to form archaeological concepts and to improve interpretation" (David and Kramer 2001).

The most widely used tool in ethnoarchaeology is 'analogy', it is a bridge by which archaeologists utilize ethnological knowledge. It helps archaeological interpretation to reflect extensively on the socio-economic behaviour of the past society through the study of a related contemporary one (society). Analogy evaluates unobserved phenomena in reference to observed ones thought to be relevant. It can be achieved in archaeological research either through the application of the 'direct historical' or the 'general comparative' approaches. Whichever one chooses, the most important issue to consider when adopting ethnoarchaeology as an approach in archaeological enquiry is whether the two traditions in question have fundamental attributes in common. The strategy will yield salient results if the two traditions are related in their environment and cultural material attributes.

Thus, this research is predicated on the fact that there exists a clear link between the extinct and the extant societies of Usambe. The contemporary inhabitants of the area are believed to be the descendants of those who lived on the Usambe hills in the past (Gundu, 1999; N dera, 2009; Ogundele 2006; Chia, 2014; and Nomishan, 2014). Oral tradition collected during the research posits that the pottery remains and other cultural indicators identified on the hills of Usambe were made and used by the past generations that settled in the area. Thus, the abundance of potsherds on the hilltops reveals a well-established society, observed to have achieved such height with an advanced scientific/ technological know-how of the past generation. The presence of same (potsherds) inspired the researcher to conduct an ethnoarchaeological study on pottery making tradition of the Usambe people. 


\section{Pottery M aking in U sambe, Ikyurav-ya}

Usambe district is subdivided into two kindred known as Usambe M ba-shahua and Usambe M ba-shin. The district is inhabited by the I kyuravya people of Kwande Local Government Area of Benue State, Nigeria. It is located within $6047^{\prime} \mathrm{N}$ and $9028^{\prime} \mathrm{E}$ and is situated within the South Eastern part of Tivland in the Middle Benue Valley (Gundu 1999; N omishan 2014).

The entire Usambe population obtain their pottery wares from one source - the wife (mama Anawase lorundu) and daughters of elder lorundu Agashua; one of the eldest persons in the community are the pottery makers. Mama Anawase lorundu is a 72 years old woman who acquired the knowledge of pottery making from her mother-in-law who also learned the craft from her mother in Nyiev (one of the Tiv communities located within the hills closer to the Nigeria-Cameroon border, further south from the Usambe area) before getting married to Late Papa A gashua (elder lorundu's father) in Usambe.

Mama Anawase has also trained all her daughters and granddaughters from 15 years and above in the craft of pottery making. They live in a compound comprising a four-room Iron house and five round huts thatched with ihila (sword grass), a kitchen and a resting hut in the middle of the compound. The compound is headed by an 89 years old papa lorundu Agashua who is a farmer. The arrangement and leadership of their compound reflect the general practice among all the families in Usambe and Tivland at large (N dera, 2006; Ogundele 2006).

The main potter is a farmer and a trader, and all her daughters are married. The granddaughters who are still living with her have all been enrolled in western education and so, none of them is practicing the tradition on full-time basis, they usually produce pots in large quantities during the dry season when most schools are on break and when there is considerably reduced labour demand in farming on the fields. It was also observed that a separate thatched house in the compound was reserved as a workshop for pottery making. However, the firing site was situated outside the compound at a distance of about $200 \mathrm{~m}$ south west of the compound.

The primary raw material for the making of pottery wares in Usambe is Inya-ityuu (clay) which is found almost all over the Ikyurav-ya and Tivland at large. The potters usually obtain their clay from the hill base and riverside. The clay is collected on the surface of the earth in some locations but in other areas, the best clay quality is mostly dug out from the ground at a considerable depth. 


\section{Preparation of the Clay (Inya-ityuu)}

Preparation of the clay starts after the clay has been mined. The potters take the clay home and spread it on sags, and use stone to break it into pieces until it is observed to be very smooth (without lumps). The clay is then soaked in water for about three or four days in a wide container (buckets, basins and big pots among others). After the clay has absorbed enough water, it is taken out and pounded in a mortar to work it into a plastic and homogeneous mass that is used to mold vessels. Sometimes, the clay is mixed with low-fired grog as temper. The grog which is usually an old broken pot is pounded, sieved, and mixed with the day. This gives the finished wares improved strength and helps its resistance to thermal shock while increasing the plasticity of the clay.

Thereafter, the homogeneous mass is cut into small masses suitable for molding desired vessels. Usambe potters use hand modeling techniques in shaping their pots. They place the base of an old broken clay vessel (oval in shape) on a flat slap of wooden plank of about $30^{2} \mathrm{~cm}$. Holding the bowl in one hand, they rotate it continuously while using the other hand to work the vessel (uhuen Ityegh or utimen Ityegh). The potters work and observe the pot while pausing at intervals to trim and scrape the vessel using lgbev (a kind of sandpaper obtained from the cover of lyiase pods). Once the desired shape is achieved, the potters immerse a mango leaf in water which she uses to hold the topmost part of the vessel while rotating it until the rim (ato a ityegh) of the vessel is formed (either everted, inverted or straight rim). Thereafter, a stick or a dried mango seed is used to form the tip of the vessel by placing the stick or the mango seed on the tip of the vessel and rotating the bowl in a single $360^{\circ}$ cirde.

Immediately after the above is achieved, the vessel is kept under a shade such that the sun cannot shine directly on it. This action enables the vessel to solidify and to allow the potter to complete the process of molding. Thereafter, the potter spreads a rag on her laps and places the vessel on it while using iyiase pod al ready immersed in water to scrape the inner part of the vessel. This is done to further smooth the vessel and in some cases, increase the size of the vessel.

The vessel is kept in the same way described above before the next phase which involves rubbing some water on the outer part of the vessel and using a little and smooth iron object to scrape the exterior part of the vessel to remove some small sand particles that may have been left in the body of the vessel. This process is repeated until the body of the vessel becomes very smooth. The vessel is again kept to dry a little before the potter applies the needed decorations. 


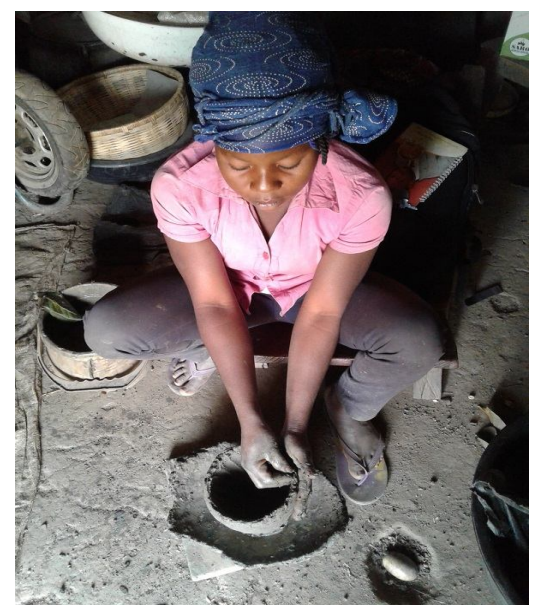

Plate 1a: Molding the pot

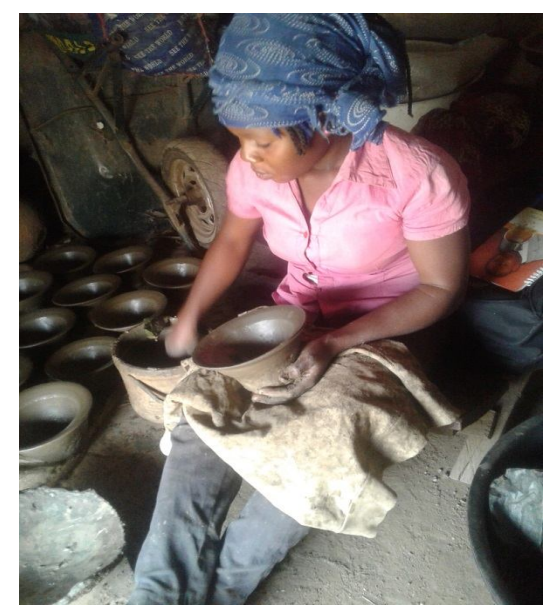

b: Forming the rim on the pot

\section{Pottery D ecorations in Usambe}

The predominant decorating techniques applied by the Usambe potters are the knitted net and mat impressions. These decorations are achieved by placing the vessel on a knitted net or a mat and using a smooth and rounded stone to hit the interior part of the half-dried vessel. The vessel is pressed into the knitted net or mat through this process, thereby leaving some decorative marks on its exterior part. This decorative motif has been hitherto found in many parts of Tivland by other researchers (Ogundele 1990; Folorunso 1993; N dera 2006; Bakinde \& Chia 2011).

Other decorations applied by Usambe potters include stamping, carved wood roulette, grooves and incisions among others. Stamping is achieved by stamping a comb, broken bones and pointed sticks on the exterior surface of the vessel. Carved wood roulette is also achieved by rolling a carved wood on the exterior surface of the vessel. Incisions, on the other hand, are achieved by using sharp and pointed objects to produce the desired decorations on the exterior surface of the vessel, while grooves are achieved by the use of objects that are pointed but blunt on the exterior surface of the vessel. 


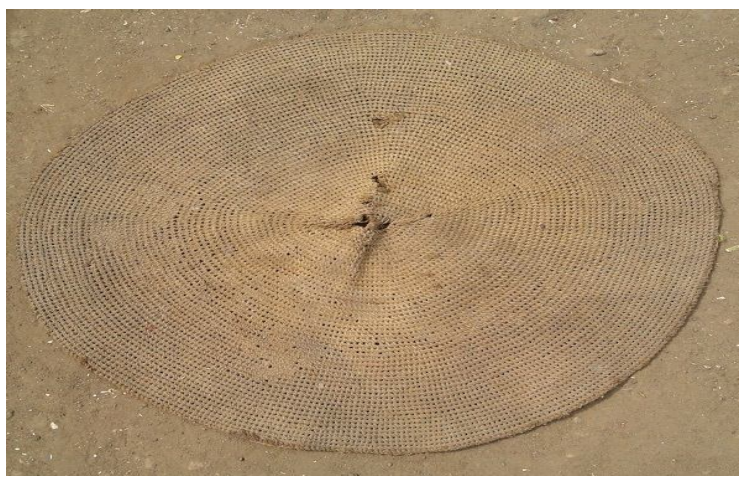

Plate 2: Knitted net used by Usambe potters for decoration

After achieving the desired decoration(s) on the vessel, the potters place the vessels in an open place to fully dry. Vessels in Usambe are dried either in the open hut (ate) or in the open air to receive sunshine. This is, however, dependent on the weather condition at a given time. This is because, during the dry season particularly in harmattan, vessels dried in the open air get cracked during firing. Therefore, once is harmattan, the potters prefer to dry their vessels in open huts (ate) particularly made for this purpose.

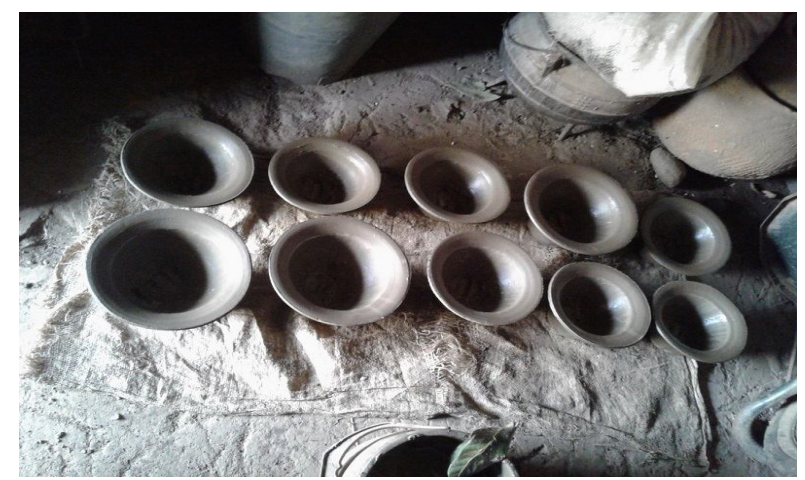

Plate 3: Drying clay pots in the hut

\section{The Firing Process}

Usambe people usually employ bonfire in firing their pottery vessels and the woods mostly used as fuel are Gbaaye (Prosopis africana), and gbagbongom (Burkea africana) among others. The potters gather as much fire woods as possible, place the vessels on them before setting the fire. H owever, the potters do not have the scientific devices to measure the exact time required for pots to be adequately fried and when to dye the vessels with a 
substance produced from a plant called ikpine (bredelia feruinea) or the required amount of heat to be supplied. They merely observed the change in colour as the vessel is fired. Once the vessels become red and extremely hot, the potter assumes that the vessels are adequately fired, and proceeds to apply the ikpine dye which turns the vessels to dark colour before they remove from the fire. Thus, vessels are sometimes fired inadequately due to miscalculations during the firing process. However, whenever this occurs, the process is repeated to get the vessels adequately fired (N dera, 2006).

The Usambe potters usually conduct bonfire at a considerable distance from the compound, as the bonfire is mostly located about 15 to 20 meters off the main compound. The reason behind this is to prevent houses roofed with thatch (ihila) from being destroyed accidentally. This point has been emphasized in several other kinds of literature on the area (N dera 2006; Bakinde \& Chia 2011). Furthermore, the Usambe potters conduct their bonfire at a distance because the community is generally situated on a hilltop and also very windy.

M ore so, the size of the Usambe potters bonfire as at the time of this research was said to be a bit large. Information from the potters indicates that they fire from 15 - 25 vessels in a single bonfire. Usambe potters produce vessels both for domestic and commercial purposes, and since it is one family that produces the vessels, the number of vessels produced at a time is directly proportional to the market demand at any given period.
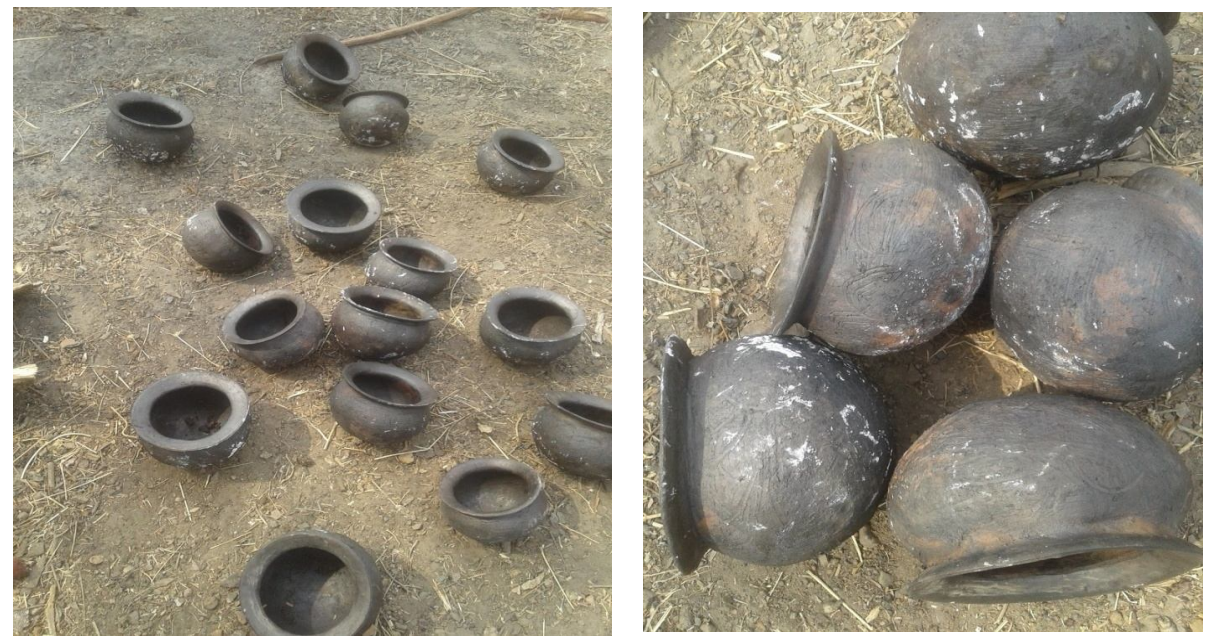

Plate $3 a \&$ b: Adequately fired and dyed pots 


\section{V essels M ade by U sambe Potters and their Functions}

Generally, Usambe potters produce a variety of pottery vessels. These indude soup pots (tsua iyue), large pots for cooking pounded yam, akpu, and turning food (tyegh ki-luam), another for processing local beer (tyegh ki-tashi), wide but shallow vessel for frying garri (ichenge), a small vessel for serving soup (gbande iyue) and a large pot for storing water (ishawa).

Usambe potters also produce small pots that are used for preparing traditional medicine. These pots are usually purchased by tradition herbalists who sell same to their patients whenever they (patients) need some concoctions from them. H owever, some patients buy the pots themselves and take to the herbalist who charges them only for their services and accepts the pot in place of his own to prepare concoction for them. Over the years, Tiv people have been observed doing this practice, with some even buying such pots in reserve for use during an emergency.

Furthermore, a variety of seeds are usually stored in large pots in the Usambe community. Some of these seeds include locust bean seed (porkie biglobosa), gbaaye seeds (prosopis Africana), and iyiase seeds (Butyrospermum parkii) among others. These particular seeds are mostly kept in such pots by older adults who prefer to keep the seeds during harvest and use or sell them in time of scarcity.

\section{D iscussion and Conclusion}

The ethnoarchaeological investigation of pottery tradition in Usambe has given the researcher the opportunity to gain insight into several factors that characterize the history of the Usambe people and Tiv in general. Information gathered during the research indicate that the past inhabitants of the area had a sophisticated pottery tradition as typified in the quality of pottery fragments found on the hills. Also, most of the decorations found on the potsherds collected on the Usambe hills are still seen on the clay wares made by the contemporary potters in the area, which indicate cultural continuity. These indude groove, incisions, roulettes, stamping, knitted net/ mat impressions and burnishing among others.

A nother insight gained into the history of the Usambe people during the research is in the area of the scientific and technological know-how of their ancestors. Their ability to know the right sites to obtain quality clay (inya tyuu), the technical knowledge to process the clay, the scientific knowhow to identify the right woods for fuel and the knowledge to determine when a vessel is adequately fired, among others, are admirable. The ancient Usambe potters knew that there are specific objects with specified sizes and shapes with which to decorate their vessels. Again, the decorations were not 
achieved haphazardly, but were carefully patterned to produce the desired results as reflected on the potsherds collected on the hills.

Furthermore, the study also revealed the different categories of vessels produced in the area and their various functions. Oral tradition collected from the contemporary Usambe people posits that their ancestors used some pots for ritual purposes, thus confirming the oral traditions about pottery tradition collected from different parts of Tivland (Folorunso 1981, 1993; N dera 2006; N omishan 2014).

So far, studies of pottery tradition in Tivland have yielded several dates. According to Ogundele (2006), research in Binda, the closest archaeological sites to the area of study, indicates that;

...potsherds were dated by the pre-dose technique, while the charcoal samples were dated by C-14 methods. The results show that the oldest vessels from the lower cultural phase of the site, were about 450 years old (16th century A.D.), while the pottery belonging to the upper phase ranges from 180 to 160 years old (18th century A.D.) (Sanni 1989: 59-64, of Ogundele 2006).

However, there has been a serious decline in the practice of pottery making. Oral information collected in Usambe community (Agbanyi pers. Comm. 2018) posits that his grandfather was the last person to abandon his residence on the Bako hill and he (Agbanyi) was about 5-8 years old when his grandfather move away from the hilltop. According to the informant (Agbanyi), there were many potters in Usambe community during this period because clay objects were the main vessels used in the area before the advent of technology that brought iron and rubber vessels much later in the Tivland.

Thus, pottery making is no long a lucrative job in Usambe and the general Tivland; this is because people prefer to use more portable and durable objects made from iron or rubber, than the clay vessels which gets easily broken at any little accident. Usambe potters currently have an insignificant market demand on their products. According to the potters, they mostly get patronage from aged people who claim that food once cooked in clay pots is better cooked than when using iron pots. Other customers that patronize their vessels include native doctors and their patients who buy the pots to use in preparing herbs for specific ailments. Thus, the must patronized pot in Usambe today is the local refrigerator (ishawa) used for storing drinking water.

Therefore, the researcher suggest that there should be more involvement and collaboration amongst relevant stakeholders. Government 
officials, research institutions, private organizations and weal thy individuals in Tivland and in the Diaspora should sponsor archaeological projects in the Ikyarav-ya and Turan areas of Kwande Local Government Area as well as the entire south eastern Tivland where claims from oral tradition suggest to be the first hills the entire Tiv race settled before spreading over the Middle Benue Valley (See Akiga 1933; Bohannan and Bohannan 1954; Gbor 1974; Makar 1975; and Orkar 1979. Others include Folorunsho (1998), Gundu (1999), Ogundele (2006), N dera (2009), Chia (2014), and N omishan (2014).

\section{References}

Akiga. S. (1933). Akiga's Story. Xeros Copy. Ibadan University Library, Ibadan.

Aremu, D.A. (2004). Nigerian Traditional craft for Self-Reliance: An Examination of the Technological significance of Aluminium pottery production in Ibadan, Nigeria. The proceedings of the 16th Conference of the Archaeological Association of Nigeria (AAN), Jos 9th - 11th Dec. 2002 (ed) Walu, L.D pp. 81-86.

Bakinde C.O \& Chia R.T (2011). Further Archaeological and Ethnographic Survey of Ushongo A rea, Benue State, Nigeria. In Journal of Nigerian Field Archaeology, Vol.1, pp. 51-65.

Bakinde, C. (2004): Ufe and Her pottery tradition. In Nigerian Tradition/ Craft for Self-Reliance. The proceedings of the 16th Conference of the Archaeological Association of Nigeria (AAN), Jos. 9th - 11th Dec. 2002 (ed.) Walu, L.D. pp 140-148.

Billington Dora, A. (1962). The Techniques of Pottery. B.T. Botsford Ltd, London.

Bohannan $P$ and Bohannan $L$ (1954). The Migration and Expansion of the Tiv. Africa. XX1V.

Chia, C.T. (2014). A rchaeological Survey of Gbanger and Mto Hills in the Hiitom Area of Ushongo Local Government, Benue State, Nigeria. Unpublished M.A Thesis, ABU Zaria.

David N . \& Kramer C. (2001). Ethnoarcheology in Action, (Cambridge), p. 2.

Ezenagu, N (2014). The Blight of African Indigenous Technology in the 21st Century. The Way Forward. Journal of Tourism and Heritage Studies 3(1):59-73.

Folorunso C.A. (1981). The Prehistoric Settlements of the Tse Dura and Ushongo Hills: A Preliminary Study. M.Sc Thesis, University of Ibadan.

Folorunso C.A. (1989). Researches sur la continuite du peuplement Tiv dans la valle de Katsina ala (Basin de la Benue au Nigeria). Sondages sur le 
site ancien d'ushongo et ethnoarchaeology de 1 habitat actuel. Ph'D Thesis, Universite Paris 1 Pantheon. Sorbonne.

Folorunso C.A. (1993). Ethnoarchaeology. Its methods and Practice: The Tiv Example. In West African Journal of Archaeology (WAJA) Vol. 23, Evi Coleman and Co, Ibadan.

Folorunso C.A. (1998). 'The Compound of the Tiv of Benue State, Nigeria: The Reality of Ethnoarchaeology' in Africa: The Challenge of Archaeology. Edited by Bassey W. Andah et al. Pp 235-255. Heinemann Educational Books(Nigeria) Plc. Ibadan.

Gbor J.W.T (1974). Tiv Traditions of Origin and Migration with Special Emphasis on the Eastern Frontier. B.A. Thesis. Ahmadu Bello University, Zaria.

Gundu Z.A. (1999): Historical Archaeology of Ancient Settlements in South Eastern Tivland, Benue State, Nigeria. Unpublished Ph'D Thesis, University of Ibadan.

Krishna L.A.I (1967). Kerela Megaliths and their Builders. (University of Madras) p. 2.

Maker T. (1975). A History of Political and Social Change Among the Tiv. Unpublished Ph.D. Thesis, A.B.U Zaria.

N dera, J.D. (2006) "Pottery Production in Tivland: An Ethnoarchaeological Perspective" Zaria Archaeological Papers" Vol.10 Journal of the Department of Archaeology, A hmadu Bello University, Zaria Pp.7891.

N dera, J.D. (2009). Archaeological Investigation of the Early Settlements of the Shitire in the Benue Valley of Nigeria. Unpublished Ph.D. Thesis, University of Ibadan.

Nicholas David \& Carol Kramer (2001). Ethnoarchaeology in Action. Cambridge. p. 2.

Nomishan T.S. (2014). An Archaeological Reconnaissance Of Kpe Hilltop Settlement Site In M baikya Community, Usambe District Of Kwande Local Government Area Of Benue State, Nigeria. Unpublished B.A. Thesis, A.B.U Zaria.

Ogundele S.O (2006). Prospects and Challenges of Oral Traditions and Ethnography for Archaeological Reconstructions: A Case Study of Tivland, Nigeria. Anistoriton Journal, vol. 10. http:/ / www.anistor.co.hol.gr/ index.htm.

Ogundele, S.O. (1990). Archaeological Investigations Into Aspects of Tiv Settlement History, Benue Valley Area, Nigeria. Unpublished Ph.D. Thesis, University of I badan, Ibadan.

Orkar J. N. (1979). Precolonial History of the Tiv of Central Nigeria. Unpublished Ph.D. Thesis, University of Dalhousie, Canada. 
Renfrew, C. and Bahn, P. (1991). Archaeology: Theories, Methods, and Practice. Mayfield Publishing Co. 